\title{
TRANSFORMATION OF METHODICAL MARKETING APPROACHES TO THE INVESTIGATION OF THE PROBLEM OF FARMING AGRICULTURAL ENTERPRISES IN THE GRAIN MARKET IN GLOBALIZATION CHALLENGES
}

\author{
Margarita Lyshenko', Tatiana Ustik², Irina Thermosa ${ }^{3}$
}

\begin{abstract}
The purpose of writing the article is to justify the methodological principles and recommendations for the functioning of agricultural enterprises-producers of grain in the target markets for its sale under the conditions of globalization challenges. The production and sale of grain traditionally remains the main focus of the specialization of domestic agricultural enterprises, the source of more than a significant share of their income, the formation and implementation of export potential of the agrarian sector of the national economy, the solution of a number of problematic issues of food security and ensuring the stable development of the subjects of the sphere of production of various sectoral belonging and orientation. At the same time, raising the economic efficiency of the main activities of agricultural enterprises remains a central problem, which in fact produces a complex, multi-faceted, and multi-level problem of the formation and functioning of mechanisms for the effective functioning of agricultural enterprises in the grain market. Research methodology. The theoretical and methodological basis of the research is the classical positions of economic theory, fundamental works, and scientific developments of domestic and foreign scientists on the effective functioning of agricultural enterprises in the grain market, the dialectic method of cognition, and the systematic approach to the study of social phenomena and processes that occur in the process of carrying out the main activity enterprises producing grain. In accordance with the goals and objectives of the article, such general scientific and special methods of economic research as monographic (in-depth study of the set tasks), abstract-logical (a theoretical generalization of the research results and formulation of conclusions and proposals) were used. Taken together, these methods form the methodological basis of the study. Results. After conducting the research, we decided that the study of the problem of the functioning of agricultural enterprises in the grain market is the study of methodological approaches to the evaluation of structural and dynamic trends of development and the state of the situation of target markets for the production of agricultural enterprises-producers of grain in the context of establishing systems supporting strategic and tactical and operational decisions in the production and commercial planes based on the system of integral indicators and individual indicators of the state of the targets. Practical use. The results of the research can be used at the state and regional levels of management in forecasting the change and the state of market equilibrium in the agrarian market of Ukraine and the conjuncture of the world and regional markets for agricultural products and food.
\end{abstract}

Key words: grain market, agricultural enterprises, globalization, indicators of grain market conditions, components of marketing mechanism in grain market, market capacity.

JEL Classification: J43, Q13

\section{Introduction}

The grain market is a unique complex economic system that covers the totality of economic relations between market players. According to objective laws, the economic mechanism of the market supports the rotation of capital, in turn organizational - carries out the regulation of production.

Objects of the grain market are commodity, money and information flows, which connect market actors through market infrastructure. Interaction of grain

\footnotetext{
Corresponding author:

${ }^{1}$ Sumy National Agrarian University, Ukraine.

E-mail:1m_1980@ukr.net

ORCID: http://orcid.org/0000-0002-6321-5178

${ }^{2}$ Sumy National Agrarian University, Ukraine.

E-mail: tanya ustik@ukr.net

${ }^{3}$ Oleksandr Dovzhenko Hlukhiv National Pedagogical University, Ukraine.

E-mail: bojarinova.ira13@gmail.com
} 
market subjects among themselves and with subjects of other agrarian markets form a cyclic circular rotation of the market and ensure the production of grain products. The main subjects of the grain market are producers and consumers of grain resources.

The main principle of the formation and development of the grain market is the adaptation of the content, form, and structure of the grain market system, tools and mechanisms of the market and state regulation to the conditions of the global environment. Violations and ignoring of the links between both functional and organizational, levelling the laws of the system's development will lead to the crisis state of the industry, and in the future to the collapse of the entire agrarian sector.

The most important contradictions of the grain market are: market requirements and grain production opportunities, the structure of the commodity supply of grain and the range of demand for grain products, the cost of grain products and the price of grain sales, etc.

The grain market situation is a complex of certain factors of social, economic, globalization, and other characters that have a significant impact on the supply and demand of grain sales and its transition from the sphere of production to the sphere of sales and consumption of grain products and products of its processing.

Globalization is a comprehensive process that deals with the economy of each individual country in its direct connection with the world economy. In the modern world, an international agrarian food system or international agribusiness system has been formed, which is a diversified and multifunctional global complex that combines the production, storage, transportation, and distribution of food products on a global scale. Economic relations in this complex are formed on the basis of international division of labour and globalization of regional agrarian food markets.

\section{Globalization factors for the formation of market conditions}

The main globalization factors shaping the grain market situation are:

- the driving factors of globalization: natural and climatic and economic-geographical differences, which predetermine the specialization of countries and cause development and deepening of interconnections between them; development of logistics systems; an increase in the openness of markets and international relations; acceleration of the pace of technological innovations and the invention of the market;

- inhibiting factors of globalization: state interference in the economy and protectionist policies; exchange rate fluctuations; political conflicts; religious restrictions; key factors of globalization: internationalization; ethics; entrepreneurship; business communication.
A comprehensive study of the grain market involves the collection, analysis, evaluation, and interpretation of data on the state, trends, and prospects of the development of the market as a whole and its individual elements, in particular, including its state of affairs. The market-oriented market analysis gives a general qualitative characteristic of its condition and determines the quantitative parameters of its demand and supply. In addition, a comprehensive study includes an analysis of the competitive environment, market infrastructure, and institutional structure of the market, an assessment of the optimal territorial placement of market actors, inter-industry and inter-territorial exchanges, as well as an assessment of the effectiveness of managerial decisions of the authorities in relation to the development of this market.

The research of scientific views has shown that there is no consensus on the group of indicators of the market situation. This situation complicates the analysis and forecasting of the market situation. After all, these factors in the calculation are conditional and relative under the influence of market conditions of the factors. We consider it expedient to allocate the following groups of volumetric economic indicators that characterize the market conditions of the grain: supply on the market; demand; the ratio of demand and supply, market conditions, business activity indicators, commercial market risks. It is these indicators that are important in determining the prospects of research and market development.

Transformation of the world community into a general, comprehensive system of socio-economic, financial, political, technological, cultural, and social ties and relationships leads to the emergence of new approaches to the economic foundations of the formation and functioning of product markets. The rapid pace of the development of such a transformation requires immediate reaction, as changes in world economic relations undeniably affect the development of the economy of an individual country. Of particular importance are the issues of adaptation of existing economic provisions in the formation and functioning of the grain market to the conditions of global integration since the importance of such strategic products cannot be overestimated. The population of the world is constantly growing; the problems of providing food are becoming priorities in conditions of uneven structure of productive forces and the social division of labour. Therefore, the scientific approach to solving these problems in the part of the study of the economic foundations of the formation and functioning of the grain market in the conditions of globalization is particularly relevant.

When studying the formation and functioning of the grain market, it should be noted that many scientists, agrarians, and economists have been studying it since Ukraine has been granted market economy status in view of the country's integration into the world trading 
system and accession to the world trade organization. It is clear that such steps have changed the basis of the economy of grain production. The key, baseline criteria and indicators, of course, remain unchanged. However, they have undergone some transformation in connection with changes in the conditions of functioning and marketing policy of commodity producers, new approaches to the interpretation of the concept of the grain market and the foundations of its formation and development.

Indicators of market conditions are universal for the market of any product and they can be systematized depending on the level of research. Table 1 shows the main indicators of market conjuncture.

The legal basis of the formation and regulation of the grain market is based on the Law of Ukraine "On Grain and Grain Market in Ukraine", which defines the state policy on the development of the grain market as a priority sector of the economy of the agro-industrial complex of Ukraine and in accordance with Art. 1 p. 23 "The grain market is a system of commodity monetary relations that arises between its actors in the process of production, storage, trade, and use of grain on the basis of free competition, free choice of grain sales and price determination, as well as state control over its quality and storage" (Law of Ukraine "On Grain and Grain Market in Ukraine", 2002). This law determines the priority of the grain market by the state, and also Section III defines the directions of state regulation of the grain market.

In accordance with the Law of Ukraine "On Protection of Economic Competition", the market of goods (commodity market) is a sphere of turnover of goods (interchangeable goods), for which there are demand and supply within a certain time period and within a certain territory (Law of Ukraine "On Protection of Economic Competition", 2001).

The basis of the modern grain market is its production in such quantities that would ensure the food security of the state and the economic safety of commodity producers. This issue was especially important in the context of globalization changes and world economic relations of our country. Integration into the world economy, development of foreign economic relations and functioning in the conditions of the world trade organization require an in-depth study of the problems of the functioning of grain producers as an open system in the external environment (Sakovska, 2011).

Due to the rapid pace of integration and globalization economic processes, the formation of the basis for the functioning of the grain market should outstrip the pace of emergence of threats and dangers associated with the entry into foreign markets (Kvitinska, 2008).

The Ministry of Agrarian Policy and Food of Ukraine, together with the National Academy of Agrarian Sciences of Ukraine, developed the Grain Ukraine-2015 Program, which outlines ways to increase grain production and outlines the technological, economic, and regulatory framework for solving the grain problem. Solving the tasks identified by the program contributed to increasing the role of our state in ensuring world food security and will outline the activities of grain producers, search for ways to ensure economic security in the conditions of globalization and expansion of world economic relations. The program outlines the agrarian policy regarding the development of the grain market, price policy, risk insurance, systems and mechanisms for regulating the incomes of commodity producers, export and import policy, and ensuring food security, measures to prevent the economic danger of commodity producers from the external and internal threats of the national market. Fortunately, in our opinion, the threats and the chain dependence of the processes of market reproduction have been formed, Nikishina O.V. (Table 2).

The new conditions of world economic relations and the functioning of world markets dictated the need for the formation of the national grain market to focus exclusively on the informational and informational

Table 1

Indicators of market conjuncture

\begin{tabular}{|l|l|}
\hline \multicolumn{1}{|c|}{ Macroeconomic } & \multicolumn{1}{|c|}{ Microeconomic } \\
\hline Gross Domestic Product & Indicators of production \\
\hline Gross national product & Transition stocks of products \\
\hline Indices of production by industry & Investment level \\
\hline The state of the labour market & Sales volumes \\
\hline The state of capital investments & Export volumes \\
\hline Price level and consumer demand & Volume of domestic consumption \\
\hline Internal turnover & Capacity \\
\hline External commodity circulation & Price dynamics \\
\hline Currency & Indicators of economic efficiency of production \\
\hline Capital turnover (money supply, exchange rates, interest) & \\
\hline The dynamics of taxation & \\
\hline The dynamics of the debt level & \\
\hline Inflation rate & \\
\hline
\end{tabular}

Source: Compiled by the author on the basis of the generalization of literary sources (Korzhivska, 2014) 
Table 2

Influence of external threats on the reproduction processes of the grain market of Ukraine

\begin{tabular}{|c|c|}
\hline \multicolumn{2}{|c|}{ Uncontrolled growth of exports of environmentally friendly Ukrainian grain crops } \\
\hline $\begin{array}{l}\text { 1. Mono production of export-oriented crops. } \\
\text { 2. The inadequacy of its own raw material base for enterprises in the } \\
\text { processing industry. }\end{array}$ & $\begin{array}{l}\text { 3. Imports of raw materials (cereals and seeds) and finished products } \\
\text { (pasta, groats, etc.). } \\
\text { 4. Increasing the cost of processing products, reducing its } \\
\text { competitiveness, strengthening the import dependence of the state. }\end{array}$ \\
\hline \multicolumn{2}{|c|}{ The dominance of foreign TNC among exporters of Ukrainian grain } \\
\hline $\begin{array}{l}\text { 1. Strengthening the price dependence of the agrarian sector on the grain } \\
\text { export policy of the exporters, who realize the interests of their states. } \\
\text { 2. Uneven export and world prices of Ukrainian grain. }\end{array}$ & $\begin{array}{l}\text { 3. Prevailing investments in the development of the port } \\
\text { infrastructure, the decline of the grain processing sub-complex, soil } \\
\text { degradation. }\end{array}$ \\
\hline \multicolumn{2}{|c|}{ The inefficiency of state support under WTO restrictions } \\
\hline 1. The ineffective activity of the Agrarian Fund in the grain market. & \multirow[b]{2}{*}{$\begin{array}{l}\text { 3. The inappropriateness of the existing methodological principles of } \\
\text { state regulation to the principles of the WTO. }\end{array}$} \\
\hline $\begin{array}{l}\text { 2. Incorrect selection of priorities within the framework of financing } \\
\text { the "yellow box" measures, lack of financing of "green" programs. }\end{array}$ & \\
\hline
\end{tabular}

Source: compiled by the author on the basis of the generalization of literary sources (Nikishina, 2011)

analytical provision of economic security of grain producers. In turn, they are the basis of the proposal in the formation of the market, and the model of the functioning and development of producers directly determines the socio-economic status at the micro, meso, and macro levels. Information and analytical support, impartiality and reliability of information help to avoid criminal, illegal actions, to prevent risks of external and internal threats and loss of competitive positions due to the lack of timely information, to prepare and conduct measures in order to prevent possible negative influences.

In order to strengthen the use of the necessary information, accounting and analytical materials, it is expedient to use the benefits of the work of management accounting specialists who, in the field of agrarian formations, should participate in solving the tasks of strategic and tactical management.

Efficient use of computer technology for management accounting should be considered as an integral part of the overall problem of improving the enterprise management process and ensuring its economic security. An effective combination of accounting and analytical information and the newest models of its processing and use in the management system will significantly increase the overall level of decisions and will allow to adjust the production processes and allow the functioning of agricultural enterprises with powerful results, which will allow entering new markets. Therefore, in order to evaluate and apply business processes to grain producers, it is expedient to use reengineering as a process of modelling activities for maximizing profits by improving the quality of services, motivating staff, reducing costs through the introduction of information technology and the complete satisfaction of information users. reengineering, as a process of modelling activities to maximize profits by improving service quality, motivating staff, reducing costs through the introduction of information technology and the complete satisfaction of user information requests.

\section{Indicators of the efficiency of economic relations in the grain market}

The structure and efficiency of economic relations in the grain product subcomplex also have a decisive influence on the formation and functioning of the grain market. It includes primary and secondary processing technology, as opposed to other types of agricultural products, grain has better storage and transportation opportunities.

Major commodity producers of grain are large agricultural enterprises, but in modern conditions, their internal structure is constantly changing. Associations arise and operate, cooperatives are created, which in turn is an impetus for the development of industrial and social infrastructure, the mechanisms of preserving the labour potential of the village. Taking into account the influence of transformational changes, this direction of development has extremely high priority. Cereal subcomplex allows the development of related industries involved in the storage, transportation, processing of products. The established cooperation of all units (provision, production, service), the possibility of producing enterprises of different forms of ownership, assistance from the state, the functioning of the national grain market can improve the efficiency of the grain industry and strengthen the position of commodity producers in the direction of strengthening their economic security.

One of the fundamentals of grain market functioning in the conditions of expansion of world economic relations is the scientific and technical development in the direction of breeding and seed production, organic grain production, biotechnology using the raw material base of cereals, improvement of animal feeding rations in the direction of optimizing the use of the grain group in order to promote livestock development. In this direction, the actual improvement of the structure of fodder grain by production and regional direction remains. The priority direction of the development of 
the grain economy is the restoration of production on irrigated lands and investments and state projects in this direction.

The generalization of the conducted research gives grounds to draw conclusions on the definition of the theoretical foundations for the formation and functioning of the grain market and an analysis of the understanding of its essence in view of globalization changes and world economic relations of Ukraine.

With the onset of the market transformation of the agrarian sector in the system of economic relations, there have been tangible structural changes. Constant price change, not matching market conditions, allows us to assert that there is no market mechanism for price regulation. Such processes negatively affect the activities of commodity producers, the definition of the market and social infrastructure, and also the formation of the purchasing power of the population.

The basis of the formation and functioning of the modern grain market is its production in such quantities that would ensure the food security of the state and the economic safety of commodity producers.

Organizational directions for the regulation of the grain market should be the creation and development of its infrastructure, the formation of the regulatory and legal framework and information and analytical support. Activation of the reproductive function of the grain market in the conditions of transformational changes in the economy and market globalization necessitates the reform of the existing regulatory mechanism in accordance with the priorities of the national grain policy. The main ones are support for the production of added value of goods, stimulation of export of finished products of processing of grain raw materials while simultaneously reducing the import of individual crops, maintaining the balance of cross-sectoral commodity and financial balances of the market, directing scientific developments in the direction of biotechnology development, increasing the area of irrigated agriculture, which is relevant in conditions of global warming and changes in climatic conditions, as well as the promotion of organic crop production (Lyshenko, 2018).

\section{Indicators of the communication and marketing structural component of the marketing mechanism of the grain market}

The evaluation of the communication and marketing structural component of the marketing mechanism of the grain market is carried out using the following formulas:

1) the share of marketing expenses in the gross sales of grain products ( $\mathrm{Sms}), \%$, is expressed in terms of the ratio of gross sales of grain products to marketing costs and multiplied by $100 \%$ :

$$
S m s=\frac{\mathrm{R}}{\mathrm{MC}} * 100 \%
$$

where Sms - share of marketing in gross sales, $\mathrm{R}$ - the amount of gross sales of grain products; $\mathrm{MC}$ - the amount of marketing expenses;

2) marketing capacity of costs Smc is expressed in terms of the ratio of marketing costs to the amount of gross sales of grain products:

$$
\text { Sms }=\frac{\mathrm{MC}}{\mathrm{R}} * 100 \%
$$

3) marketing capacity of expenses in gross expenditures $\mathrm{ms}$ is expressed in terms of the ratio of the amount of marketing expenses to gross expenditures:

$$
M C m c=\frac{\mathrm{MC}}{\mathrm{DC}}, \%
$$

where DC - gross expenditures;

4) the profitability of marketing and marketing costs of grain products (Rms) is expressed through the ratio of profit to the amount of marketing costs:

$$
R m s=\frac{\mathrm{P}}{\mathrm{MC}}, \%
$$

where $\mathrm{P}$ - profit (financial result) from the sale of grain products;

5) marketing capacity of net profit:

$$
R m s=\frac{1}{\mathrm{Rms}}, \%
$$

6) the rate of increase in revenues from additional invested marketing costs (Grims) is expressed by the ratio of interest rate dynamics of income growth to the percentage dynamics of marketing costs and is calculated by the formula:

$$
\text { Grims }=\frac{\Delta \mathrm{In} \%}{\Delta \mathrm{MC} \%}
$$

where $\Delta \mathrm{In} \%$ - Percentage of income growth; $\Delta \mathrm{MC} \%$ Percentage of marketing costs;

7) the coefficient of growth of the increase in the volume of sales of grain products from increased costs $(\triangle \mathrm{MC} \%)$ is expressed by the ratio of the growth rate of sales to the growth rate of marketing costs:

$$
\Delta M C \%=\frac{\Delta \mathrm{S} \%}{\Delta \mathrm{MC} \%}
$$

where $\Delta S \%$ - the growth rate of sales; $\Delta \mathrm{MC} \%$ - the growth rate of marketing expenses;

8) The return on investment (ROI) is calculated by the formula:

$$
R O I=\frac{\mathrm{S}-\mathrm{Mi}}{\mathrm{Mi}}, \%
$$

where $S$ - volumes of sales, the income of the agricultural enterprise, $\mathrm{Mi}$ - marketing investments; 9) profitability of marketing investments (ROMI) is expressed through the ratio of income received as a result of marketing actions, to marketing investments:

$$
\text { ROMI }=\frac{\mathrm{Sm}}{\mathrm{Mi}}, \%
$$

where $\mathrm{Sm}$ - revenue generated as a result of marketing actions, $\mathrm{Mi}$ - marketing investments;

The communication priority coefficient (Kpi) helps identify trends that are least developed and at 
the same time most relevant, that is, those areas of communication activity that should be mentioned as a priority, for which the agricultural enterprise must first direct marketing efforts:

$$
K p i=\frac{\text { Ofi }}{\text { Obi }} * 100 \%
$$

where Ofi - actual evaluation of marketing efforts in the i-m direction, scores; Obi - desirable (necessary) evaluation of marketing efforts in the i-m direction, points.

If Kpi $>100 \%$, this means that marketing efforts in this direction should be weakened because the relevance is directly less than its activity.

If $\mathrm{Kpi}=100 \%$ is an ideal ratio, which indicates that the marketing efforts of the enterprise fully meet the need for them.

If $\mathrm{Kpi}<100 \%$, this means that the direction needs to be intensified marketing efforts, that is, the actual direction is given insufficient attention to its use by the enterprise.

The evaluation of the effectiveness of the marketing management system, as a structural component of the marketing mechanism for the development of the agricultural enterprise of the grain sector, will be expressed by three main indicators:

1) the ratio of revenues from the sale of the i-th event to the expenses for the implementation of $\mathrm{i}$-th measure:

$$
R i=\frac{\mathrm{Di}}{\mathrm{MCi}},
$$

where $\mathrm{Di}$ - income from the realization of the $\mathrm{i}$-th event, $\mathrm{MCi}$ - expenses for the implementation of the i-th event;

2) the ratio of the absolute growth rate of income from the realization of the $\mathrm{i}$-th event to the growth rate of expenditures for the implementation of the $\mathrm{i}$-th measure:

$$
\Delta R i=\frac{\Delta \mathrm{Di}}{\Delta \mathrm{MCi}},
$$

3 ) the ratio of relative growth rates of income from the implementation of the $\mathrm{i}$-th event to the growth rates of expenditure for the implementation of the $\mathrm{i}$-th event:

$$
\Delta R i \%=\frac{\Delta \mathrm{Di} \%}{\Delta \mathrm{MCi} \%},
$$

Getting the most accurate data when evaluating the effectiveness of structural components of the marketing mechanism for the development of agricultural enterprises is possible only with attention to the synthesis of methods of qualitative and quantitative analysis. To this end, the study used integrated methods that allow a profound and qualitative assessment of the effectiveness of the marketing mechanism, identify the potential for improvement of certain indicators, which will help to adjust the activities of the agricultural enterprise in the context of strategic development.

One of the key characteristics of the grain market and an integral part of the analysis of the marketing activity of the enterprise is the capacity of the market. This economic indicator allows you to analyse the actions of all market players (sellers and buyers) in a certain time period and formulate a program of actions for the future.

In particular, the study of the capacity of the grain market of food resources is used in determining the level of food security of the state. The assessment of the capacity of the grain market is an important stage in the compilation of actual and forecast balances of demand and supply of agricultural products and food markets. This indicator is widely used in the development of marketing strategy for agricultural and processing enterprises. In addition, it is used for an objective assessment of the situation and dynamics of changes in the market and, accordingly, the adoption of the only effective management decisions that will further affect the viability of a single product or enterprise and the country as a whole (Shpichak, Lupenko, Zhuk, 2013).

In the theory of question, in principle, there was a certain consensus on the definition of the basic categories underlying our research, such as: "market capacity" and "entrepreneurial motivation" (see Table 3 ). However, according to our belief, the institutional, which will give them the colour of interdisciplinarity, is definitely an aspect of novelty to a purely economic positioning.

We agree with the research of Pehov V. A. in part of the theoretical positions for the basic institutional constructs of theoretical and practical recognition of its content characteristics should be considered "capacity of the market" and "motivation of entrepreneurial activity". Their ratio indicates their interdependence because the capacity of the market is actually the actual or potential volume of the sale of the goods, and the economic interest is the motivation of entrepreneurial acts (production, sales, etc.), in this case, in the grain market. This is a somewhat simplistic approach to the definition, but the logic of connections is precisely this, but their basis is the conjuncture - the balance of supply and demand.

The process of forming the motivation of entrepreneurship in the production of grain by agricultural enterprises, as well as other participants in the market of the same name (households, farms) is regulated by the institutional factors of the subjective (employee, entrepreneur) and objective (market, market law) order. However, they are all one way or another mediated by cost, its objective law, so in this case, we consider motivation through the prism of the cost and price as the all-embracing quintessential of imitation of motivations in the market system.

Among the empirical indicators - the definitions of the state of the grain market and the motivation of entrepreneurship, we selected the indicators of production, sales, costs, prices, incomes of consumers, which, in the relevant estimates, constitute a general picture of the national scale, outlining the foundations for proposals for the elimination of deficiencies. 
Table 3

Substantive characteristics of the conceptual apparatus of scientific institutionalization of market capacity

\begin{tabular}{|l|l|}
\hline \multicolumn{1}{|c|}{ Content } & \multicolumn{1}{c|}{ Author or Source } \\
\hline $\begin{array}{l}\text { The possible volume of sales of goods (works, services) at a } \\
\text { certain level of prices is calculated in quantitative (quantity } \\
\text { of goods sold) and monetary value (the amount of money } \\
\text { for the sold goods) }\end{array}$ & $\begin{array}{l}\text { Shpichak O. M., Lupenko Yu. O., Zhuk V. M. etc. (2013). Capacity of the } \\
\text { internal consumer market for agricultural products and food: monograph. } \\
\text { K.: NSC IAE, 186 p. } \\
\text { Shchich O. M., Bodnar O. V. (2013). Problems of the Capacity of the } \\
\text { Internal Consumer Market for Agricultural Products and Food in Ukraine } \\
\text { in the Context of the Purchasing Power of the Population. Economy of the } \\
\text { agroindustrial complex. № 6. pp. 5-13. }\end{array}$ \\
\hline $\begin{array}{l}\text { Quantitative estimation of market volume in natural or cost } \\
\text { indicators }\end{array}$ & $\begin{array}{l}\text { Kobuta I. V. (2006). Features of agrarian policy of the European Union in the } \\
\text { grain market. Economy of agroindustrial complex. No 5. pp. 110-118. }\end{array}$ \\
\hline $\begin{array}{l}\text { The potentially possible volume of sales of a particular } \\
\text { product on the market during a specified period, which } \\
\text { depends on demand for goods (work or service), price } \\
\text { level, general market conditions, incomes, business activity }\end{array}$ & $\begin{array}{l}\text { Novoselskaya L. I., Tsigush Yu. Yu. (2009). International experience in } \\
\text { calculating the subsistence minimum. Scientific Bulletin of NLTU of Ukraine. } \\
\text { Vip. 19.4. pp. 198-200. }\end{array}$ \\
\hline $\begin{array}{l}\text { The institutionalized balance of demand for goods, } \\
\text { which, within the limits of certain market conditions and } \\
\text { consumer incomes, provides the corresponding potential } \\
\text { (volume) of realization }\end{array}$ & $\begin{array}{l}\text { Pehov V. A. Formation of market capacity and motivation of entrepreneurship } \\
\text { in grain production: theoretical and methodological aspects of essence. Effective } \\
\text { economy. Mode of access: http://www.m.nayka.com.ua/?op=1\&j=efektyvna- } \\
\text { ekonomika\&s=ua\&z=4338 }\end{array}$ \\
\hline
\end{tabular}

We will note earlier, confirming the above-mentioned thesis that the issue of market capacity and the formation of the motivation of entrepreneurship in the production of grain in its practical implementation has a special institutional nature, since the question is not purely economic benefit, because grain is a social product - its presence is of globally-security nature. Therefore, the size of production is actually stable, especially for Ukraine.

We believe that the formation of market capacity and the motivation of entrepreneurship in grain production empirically position the trends-role parameters of its significance for the national economy since the grain economy initially defined both general and, to a large extent, the general economic effects of profitability, food security, etc. Grain production is a top priority because due to the institutional conditions that have developed today (population growth in the world, energy problems), grain demand is increasing and reserves for increasing its production in Ukraine are significant.

According to the calculations of scientists of the National Research Centre "Institute of Agrarian Economics", the share of grain and leguminous crops in the structure of gross agricultural output of Ukraine is increasing. Thus, their share in 1990 was $18.9 \%$ (53.3 billion UAH), in $2000-18.0 \%$ ( 27.2 billion $\mathrm{UAH}$ ), and in $2010-21.4 \%$ (41.6 billion UAH), in $2011-25.9 \%$ (60.5 billion UAH), in $2012-22.1 \%$ (49.4 billion UAH). This analyst indicates a fairly high capacity of the market and, in particular, a steadily growing motivation for entrepreneurs to produce grain.

The production of grain is extremely important for the domestic agro-economic complex of the industry, which has historically developed, due to the natural-economic, national-identical, and institutional conditions. Ukraine grows in the countryside, and the countryside has always produced grain because it is the main "currency of success", the product of agricultural labour - the most liquid in the territory of our state and beyond. The question is not simply the expediency of producing grain products but in the most effective economic order, which will provide growing effects.

The study of the problem of market capacity and the formation of entrepreneurial activity in the production of grain has established that these institutional studies are special in essence, significance, and positioning, they should be considered in the context of interdependence, but national identical attributes of economic existence (traditions of consumption, efficiency, desire to produce grain products etc.) show a number of differences, which are often difficult to adjust to the logic of the functioning of the market mechanism. Here we mainly draw attention to the traditions, because the Ukrainian peasant is an original bread-grower, for him the production of grain is an effect irrespective of the market situation. Concretely, we will also make proposals in solving existing problems, we believe that entrepreneurs are motivated in advance to develop this type of economic activity, and the market capacity can still be balanced by a broad state campaign for the promotion of grain products to the external market (Lyshenko, 2015).

According to the scheme of forecasting balances, which is presented in the Methodology for compiling forecast balances of demand and supply of food resources approved by the Ministry of Economy of Ukraine (Retrieved from: http://me.kmu.gov.ua/uk/ publish, 2009), the assessment of the capacity of the grain market is carried out according to the following formula:

Capacity $=$ Change in stocks + Production +

+ Imports - Exports 
Paskhaver B. Y., in his research (Paskhaver, Shubravska, Moldova, 2009), notes that the capacity of the grain market is shaped by the influence of such macroeconomic factors as the solvency of the population, the state of development of the agrarian sector, and the rationality of foreign economic activity.

Depending on the subject of the analysis, the author believes that it is necessary to determine the capacity of the market for individual products. The capacity of the market for a single product is determined by the formula:

$$
M P i=C i \times Ц i \times H,
$$

where: MRI - the capacity of the market of the i-th product, UAH;

$\mathrm{Ci}$ - the consumption of the $\mathrm{i}$-th product per person per year, kg;

These are the average annual consumer price of $1 \mathrm{~kg}$ of product, UAH;

$\mathrm{H}$ - the number of population, persons

The normative capacity of the internal grain market is defined as the sum of the products of the rate of consumption of the population of a certain type of food and the average consumer price for this type of food. The calculation is made on the entire population of the country.

$$
E R P=\sum(H c n * C p n) * H,
$$

where: ERP - the capacity of the internal market of food, UAH;

Hcn - the rate of consumption of the n-th type of food per capita, $\mathrm{kg}$;

$\mathrm{CPn}$ - consumer price of the n-th type of food, UAH;

$\mathrm{H}$ - average annual population, persons;

$\mathrm{n}$ - the kind of food resources that form the capacity of the internal food market;

c - the number of types of food resources that form the capacity of the internal food market.

If consumer prices for foodstuffs are used to calculate the normative volume of the food market, the range is specified in the set of approved by the Cabinet of Ministers of Ukraine Decree No. 656 "On Approval of Nutrition Sets, Sets of Non-Food Products and Service Sets for Major Social and Demographic Groups" (Retrieved from: http://zakon1.rada.gov.ua/cgi-bin/ laws $/$ main.cgi?nreg=656-2000-\%EF., 2000 ), in this case, the general formula of the market capacity will look like

$$
E R P=\sum(P x n * C C k) * H,
$$

where: Рхк - the volume of the k-th food product by one person of a certain sociodemographic group in a year, $\mathrm{kg}$;

$\mathrm{CCk}$ - average consumer price of the k-th food product, indicated in the set, UAH;

$\mathrm{H}$ - average annual population, persons;

$\mathrm{k}$ - kind of food resources that form the capacity of the internal food market; $\mathrm{d}$ - the number of types of food resources that form the capacity of the internal food market.

The normative capacity of domestic agricultural markets is determined in the natural indices for each type of production. In particular, the capacity of the internal grain market is determined by the formula:

$$
\begin{aligned}
& \text { ER grains }=(\mathrm{Ns} \text { prz }+\mathrm{Ns} \mathrm{fz}) / 1000 \times \mathrm{N}+ \\
& +\mathrm{Fn}+\mathrm{Fpp}+\mathrm{Vtr},
\end{aligned}
$$

where: Ns prz - the standard of consumption of food grain per one person, $\mathrm{kg}$;

$\mathrm{Ns} \mathrm{fz}$ - norm of consumption of fodder grain per one person, $\mathrm{kg}$;

$\mathrm{H}$ - average annual population, thousand persons;

Fn - normative volume of the seed fund, thousand tons;

Fpp - the amount of grain used for processing of products for non-food purposes, thousand tons;

Vtr - the amount of grain losses, thousand tons (Paskhaver, Shubravska, Moldova, 2009).

\section{Conclusions}

It is expedient to show the methodology of managing the efficiency of the activity of commodity producers in the grain market from three perspectives: through the clarification of the regularities and objective processes taking place in the grain market, consideration of these features within certain scientific concepts and methods, the creation of a rational model of the grain market; due to the identification of probable conflicts and risks for grain market players, giving priority to economic feasibility and increasing the efficiency of using market principles in view of compliance with legal norms and changes in the organizational and legal basis of the activities of enterprises participating in commercial processes in the market; because of the consideration of the results of the production activity of agricultural enterprises as a material and objective basis of the market, an organic combination of marketing research with the monitoring of the production and commercial potential of commodity producers.

It was established that the main globalization factors shaping the market situation of the domestic grain market are: driving factors of globalization (natural and climatic and economic-geographical differences, which predetermine the specialization of countries and cause development and deepening of interrelations between them, development oflogistics systems, growth openness of markets and international relations, acceleration of technological innovations and withdrawal of inventions in the market); inhibiting factors of globalization (state interference in the economy and protection policies; fluctuations in exchange rates; political conflicts; religious restrictions; key factors of globalization: internationalization; ethics; entrepreneurship; business communications). 


\section{References:}

Korzhenivska, N. L. (2014). Ekonomični osnovy formuvannja j funkcionuvannja rynku zerna v umovakh hlobalizaciji svitohospodarskykh zvjazkiv Ukrajiny [Economic principles of the formation and functioning of the grain market in the conditions of the globalization of world economic relations of Ukraine]. Current problems of development economy of the region, $10(1), 17-24$.

Pro zerno ta rynok zerna v Ukrajini (2002). [About grain and grain market in Ukraine]: Law of Ukraine dated July 4, № 37 / IV. Bulletin of the Verkhovna Rada of Ukraine, № 35, p. 258 (with changes).

Pro zakhyst ekonomichnoji konkurenciji (2001). [On Protection of Economic Competition]: Law of Ukraine dated January 11, No. 2210-III. Bulletin of the Verkhovna Rada of Ukraine, № 12. Art. 64 (with changes).

Sakovskaya, O. (2011). Ekonomichni zasady orghanizaciji ta funkcionuvannja reghionaljnogho rynku zerna [Economic principles of the organization and functioning of the regional grain market]. Retrieved from: $\mathrm{http} / /$ sophus.at.ua/publ/2011_11_15_16_kampodilsk/section_5_2011_11_15_16/ekonomichni_zasadi_ organizacij ta funkcionuvannja_regionalnogo ri nku_zerna/7-1- $\overline{0}-\overline{16} 3$

Kvitinska, U. I. (2008). Formuvannja zovnishnjotorghiveljnykh vidosyn na rynku zerna v Ukrajini [Formation of foreign trade outlets on the grain market in Ukraine]. Economics. Retrieved from: http://www.rusnauka.com/ 33 NIEK 2008/Economics/37199.doc.htm

Ni-̄ishina, O. V. (2011). Strateghija rozvytku derzhavnogho rynku zerna v umovakh ghlobalizacijnykh vyklykiv [Strategy for the development of the state grain market in the context of globalization challenges]. Problems of the Formation of a New Economy in the 21st Century (Dnipropetrovsk, December 22-23, 2011), At 8t. T.2. Dnipropetrovsk: Bila K. O.

Lyshenko, M. O. (2018). Efektyvnistj funkcionuvannja siljsjkoghospodarsjkykh pidpryjemstv na rynku zerna: naukovi osnovy, stan, perspektyvy [Efficiency of functioning of agricultural enterprises in the grain market: scientific fundamentals, state, prospects]. Monograph. Burin: PE "Burinsky District Printing House".

Shpichak, O. M., Lupenko, Yu. A., Zhuk, V. M. (2013). Jemnistj vnutrishnjogho spozhyvchogho rynku siljsjkoghospodarsjkoji produkciji ta prodovoljstva [Capacity of the Internal Consumer Market for Agricultural Products and Food]. Monograph. K.: NSC "IAE".

Pro zatverdzhennja Metodychnykh rekomendacij skladannja proghnoznykh balansiv popytu i propozyciji prodovoljchykh resursiv [On Approving the Methodological Recommendations for the Preparation of Forecast Balances of Demand and Supply of Food Resources]. Order of the Ministry of Economy of Ukraine dated December 18, 2009, No. 1426. Retrieved from: http://me.kmu.gov.ua/uk/publish

Paskhaver, B. Y., Shubravska, O. V., Moldavan, L. V. (2009). Vyklyky i shljakhy aghroprodovoljchogho rozvytku [Challenges and ways of agri-food development]. National Academy of Sciences of Ukraine; Institute of Economics and Forecasting. K.

Pro zatverdzhennja naboriv produktiv kharchuvannja, naboriv neprodovoljchykh tovariv ta naboriv poslugh dlja osnovnykh socialjnykh i demoghrafichnykh ghrup naselennja [On approving sets of food products, sets of non-food products and sets of services for major social and demographic groups $]$ : Resolution of the Cabinet of Ministers of Ukraine dated April 14, 2000, No. 656. Retrieved from: http://zakon1.rada.gov.ua/cgi-bin/laws/ main.cgi?nreg=656-2000-\%EF

Lyshenko, M. O. (2015). Osnovni problemy rozvytku rynku zerna ta metody pidvyshchennia efektyvnosti yoho vyrobnytstva [Basic problems of the development of grain market and the methods of improving the efficiency of its production]. Bulletin of Sumy National Agrarian University. Scientific Journal. Series "Economics and Management", no. 5(64), pp. 37-45.

Lyshenko, M. O., Makarenko, N. O., Makarova, V. V., Mushtay, V. A. (2018). Orhanizatsiyne ta ekonomichne rehulyuvannya rynku zerna $\mathrm{v}$ umovakh staloho rozvytku [Organizational and Economic Regulation of the Grain Market in Conditions of Sustainable Development]. Journal of Environmental Management and Tourism. SPRING. Volume IX. Issue 1(25). Pp. 95-104.

Mushtai, V., Lyshenko, M., Makarenko, N. (2018). Zabezpechennya vyrobnytstva zerna v umovakh staloho rozvytku. [Provision of grain production in conditions of sustainable development]. Monograph. LAP LAMBERT Academic Publiching.

Pilarczyk, B., Nesterowcz, R. (2010). Marketing ekologicznych produktów żywnósciowych. Warszawa: Wydawnictwo Oficyna a Wotters Kluwer business.

Pilarski, S., Grzybowska, M., Brzeziński, M. (2003). Rynek zywności ekologicznej. Seria: Monografie i rozprawy. Łomża: Wydawnictwo Wyżsej Skoly Agrobiznecu w Łomży. 